\title{
Instytucjonalne koncepcje wsparcia oszczędzania w gospodarstwach domowych o niskich dochodach
}

\author{
Institutional concepts of saving support for low-income households
}

\section{Wprowadzenie - sformutowanie problemu badawczego}

Neoklasyczne teorie oszczędzania, oparte na propozycjach Ando i Modiglianiego oraz Friedmana, zakładają, że gospodarstwa domowe są szczególnie zainteresowane długoterminowymi celami konsumpcyjnymi, a oszczędzanie jest najlepszym sposobem na wygładzenie konsumpcji, jako reakcja na zmienność dochodu gospodarstwa domowego (Harasim, 2007, 2010). W odróżnieniu od teorii neoklasycznych, w podejściu behawioralnym, opartym na pracach Duesenberry’ego, Kantony, van Raaija, a także w szczególności Shefrina i Thalera, zwraca się uwagę na problem w realizacji tych długoterminowych celów konsumpcyjnych, spowodowany głównie brakiem samokontroli i preferencją czasu teraźniejszego (Rószkiewicz, 2004; Białowąs, 2013)ํ.

Oprócz powyższych argumentów, jedną z ważniejszych interwencji, wskazywanych w latach po kryzysie finansowym 2007/2008 w literaturze poświęconej oszczędzaniu, jest rozwój tzw. financial literacy (FL) (Lusardi \& Mitchell, 2011; Bucher-Koenen \& Lusardi, 2011; Klapper, Lusardi \& Panos, 2013; Son \& Park, 2017). Z wyników tych badań wynika, że im wyższy jest poziom FL, tym wyższy jest

${ }^{1}$ W artykule za teoretyczny punkt wyjścia, zgodnie z podejściem Thalera $(1990,1994,2000)$ $\mathrm{w}$ dyskusji poświęconej instytucjonalnym mechanizmom oszczędzania, przyjmuje się teorię racjonalnego wyboru (ang. theory of rational choice lub rational choice theory) oraz szereg implikacji behawioralnych, które tę racjonalność zaburzają (ang. decision's bias). Równie istotny nurt teoretyczny (który nie zostanie omówiony) opiera się na modelu poznawczym konsumenta na rynkach finansowych (Ajzen \& Fishbein, 1980; Antonides \& Van Raaij, 2003; Xiao, 2008). 
poziom kumulowanych oszczędności. Okazuje się jednak, że w przypadku gospodarstw domowych o niskich dochodach wpływ zmiennej FL może być ograniczony, a rozwój tych kompetencji może wynikać z wpływu determinant o charakterze instytucjonalnym. Przykładem takiej argumentacji mogą być badania Cucinelli, Trivellato i Zenga (2019), którzy wskazali, że rozwój FL we Włoszech zależy przede wszystkim od wpływu uwarunkowań zewnętrznych (ang. local context). Z badań tych wynika, że wśród determinant, które mogą w istotny sposób decydować o wyborach finansowych w tych gospodarstwach, dominują te wywodzące się z mądrości ludowej danej społeczności (zasilane normami i regułami postępowania charakterystycznymi dla danej społeczności lokalnej). Te wyniki zgadzają się z wieloma innymi badaniami w tym zakresie. Podsumowując przegląd badań, nobliści Banerjee oraz Duflo (2011, s. 59) wskazali, że „gospodarstwa domowe o niskich dochodach dokonują wyborów na podstawie tego, co ma dla nich sens, jednak ze względu na to, że większość z członków tych gospodarstw nie posiada dyplomu wyższej uczelni, jak również nie ma powodu, aby ufać kompetencji doradców, ich wybory są w gruncie rzeczy strzałem w ciemno". Z tego powodu skuteczne podnoszenie FL wśród gospodarstw domowych o niskich dochodach powinno być osadzone w kontekście instytucjonalnym.

Specyfika problemów finansowych, z jakimi radzą sobie gospodarstwa domowe o niskich dochodach, dotyczy zatem zarówno aktywów, jak i pasywów bilansu gospodarstwa domowego, a także wpływu szeregu czynników (psychologicznych, zdolnościowych i instytucjonalnych), powodując, że wielu badaczy zaczęło tworzyć nowe koncepcje i teorie oszczędzania, dedykowane właśnie gospodarstwom domowym o niskich dochodach (Sherraden, 1991; Schreiner \& Sherraden, 2007; Han \& Sherraden, 2009). Celem artykułu jest przedstawienie argumentów teoretycznych i badawczych wspierających następującą tezę badawczą: „Brak oszczędzania w gospodarstwach domowych o niskich dochodach wynika m.in. $z$ braku instytucjonalnego wsparcia tych gospodarstw w realizowaniu zarówno krótko-, jak i długoterminowych planów oszczędnościowych". Cel zostanie zrealizowany, po pierwsze, poprzez krytyczny przegląd sformułowanych instytucjonalnych teorii oszczędzania dedykowanych gospodarstwom domowym o niskich dochodach, po drugie zaś - poprzez ocenę adekwatności i praktyczności istniejących instytucjonalnych koncepcji i teorii oszczędzania w stosunku do gospodarstw domowych o niskich dochodach. 


\section{Instytucjonalne koncepcje i teorie oszczędzania w gospodarstwach o niskich dochodach - krytyczny przegląd literatury}

Determinanty ekonomiczne i demograficzne tylko w ograniczonym zakresie wyjaśniają problem niskich oszczędności w gospodarstwach domowych o niskich dochodach. Z tego powodu, także w polskich badaniach z tematyki oszczędzania, poszukuje się ograniczeń teorii neoklasycznych, głównie poprzez wskazywanie osiągnięć teorii behawioralnych (jak wynik wpływu zmiennych psychologicznych) (Rószkiewicz, 2006, 2014; Kłopocka, 2018).

Twórcy podejścia instytucjonalnego wskazują, że na procesy oszczędzania poza dochodami i preferencjami - mogą mieć wpływ inne czynniki. W opinii Mullainathana i Shafira (2014), jak również Collinsa (2015) oraz Halperna (2015) należy ich poszukiwać w grupie determinant:

- psychologicznych (m.in. problem samokontroli, preferencji czasu teraźniejszego, braku motywacji),

- zdolnościowych (m.in. niski poziom FL, brak doświadczeń z produktami finansowymi, brak umiejętności zarządzania nieoczekiwanymi wstrząsami finansowymi),

- instytucjonalnych ${ }^{2}$ (m.in. brak dostępu do właściwych produktów i usług finansowych, systemu wsparcia), które poprzez tworzenie właściwych rozwiązań instytucjonalnych mogą ograniczać negatywny wpływ determinant psychologicznych i zdolnościowych.

Sformułowany przez Sherraden i współpracowników na przestrzeni prawie dwóch dekad instytucjonalny mechanizm wsparcia oszczędzania w gospodarstwach domowych o niskich dochodach opiera się właśnie na wynikach empirycznych, uwzględniających te trzy grupy determinant. Składa się on z siedmiu komponentów i zaprezentowany jest w tabeli 1.

${ }^{2}$ Pisząc o środowisku instytucjonalnym, autor korzysta głównie z definicji Dortha, który, opisując instytucje, miał na myśli zestaw formalnych reguł (konstytucja, przepisy prawne, prawa własności, kodeksy postępowania branżowego) i nieformalnych (normy moralne i religijne, przesądy, tradycje, zwyczaje, wzory kulturowe, sankcje społeczne), które wpływają na sposób, w jaki ludzie dokonują wszelkich wyborów (finansowych, zawodowych, społecznych czy rodzinnych) w danej społeczności (North, 1991, s. 97; Iwanek \& Wilkin, 1997; Wilkin, 2016). 
Tabela 1. Komponenty instytucjonalnego mechanizmu oszczędzania w gospodarstwach domowych o niskich dochodach

\begin{tabular}{|l|l|l|}
\hline $\begin{array}{c}\text { Ewolucja } \\
\text { mechanizmu }\end{array}$ & \multicolumn{1}{|c|}{ Nazwa komponentu } & \multicolumn{1}{c|}{ Opis } \\
\hline 1.1 & $\begin{array}{l}\text { Właściwie przygotowana } \\
\text { informacja (ang. informa- } \\
\text { tion lub targeted financial } \\
\text { education) }\end{array}$ & $\begin{array}{l}\text { Dostarczanie informacji uwzględniającej } \\
\text { ograniczenia w zakresie FL, ograniczeń po- } \\
\text { znawczych, oraz inklinacji behawioralnych, } \\
\text { jak również prowadzenie projektów edu- } \\
\text { kacji finansowej w obszarach największych } \\
\text { braków FL }\end{array}$ \\
\hline 1.2 & $\begin{array}{l}\text { Mechanizm zachęt } \\
\text { (ang. attractive savings } \\
\text { incentives) }\end{array}$ & $\begin{array}{l}\text { Oferowanie bonusów finansowych za szereg } \\
\text { aktywności w procesie oszczędzania, m.in. } \\
\text { rozpoczęcie procesu oszczędzania, systema- } \\
\text { tyczność w procesie, zakonczenie procesu }\end{array}$ \\
\hline 1.3 & $\begin{array}{l}\text { Dostęp do usług finan- } \\
\text { sowych (ang. access lub } \\
\text { institutionalized saving } \\
\text { mechanisms) }\end{array}$ & $\begin{array}{l}\text { Dostęp do produktów finansowych, które są } \\
\text { proste, niskokosztowe i wspierają realizację } \\
\text { celów oszczędnościowych krótko- i długo- } \\
\text { terminowych }\end{array}$ \\
\hline 2.4 & $\begin{array}{l}\text { Mechanizm wsparcia } \\
\text { (ang. facilitation) }\end{array}$ & $\begin{array}{l}\text { Tworzenie produktów i usług finanso- } \\
\text { wych, opierając się na dorobku ekonomii } \\
\text { behawioralnej, m.in. opcje domyślne }\end{array}$ \\
\hline 2.1 & $\begin{array}{l}\text { System oczekiwań } \\
\text { (ang. expectation) }\end{array}$ & $\begin{array}{l}\text { Określanie miesięcznych celów oszczędnoś- } \\
\text { ciowych wraz z wykorzystywaniem efektu } \\
\text { presji społecznej (poprzez tworzenie grup } \\
\text { wspólnego oszczędzania) }\end{array}$ \\
\hline (ang. security)
\end{tabular}

Źródło: opracowanie własne na podstawie Sherraden (1991, s. 116), Beverly i Sherraden (1999, s. 463), Sherraden, Schreiner i Beverly (2003, s. 97), Han i Sherraden (2009, s. 476).

W pierwszej kolejności instytucjonalny mechanizm oszczędzania w gospodarstwach o niskich dochodach obejmował cztery komponenty opisane punktami 1.1-1.4 (Beverly \& Sherraden, 1999). Następnie, na podstawie badań własnych został rozszerzony do sześciu elementów - uzupełnienie stanowiły punkty 2.1-2.2 (Sherraden, Schreiner \& Beverly, 2003). Finalnie składał się on z siedmiu komponentów, uwzględniających także punkt 3.1 (Han \& Sherraden, 2009)3.

${ }^{3}$ Należy także podkreślić, że mechanizm ten pojawia się w pracach innych badaczy, którzy zajmują się problemem decyzji finansowych, m.in. w propozycji Thalera i Sunsteina (2003, 2008), sformułowanej w ramach podejścia libertariańskiego paternalizmu, a także w propozycji 
Tradycyjnie oferowane produkty i usługi bankowe uwzględniają dwa komponenty opisanego w tabeli 1 systemu: dostęp do usług finansowych, bezpieczeństwo oraz częściowo ograniczenia związane z wybieraniem środków. Natomiast pozostałe komponenty najczęściej nie występują. Należy zatem omówić zwłaszcza pozostałe komponenty, gdyż ich znacznie może być szczególnie istotne w procesie tworzenia rozwiązań dla gospodarstw domowych o niskich dochodach.

W pierwszym przypadku jest to właściwie przygotowana informacja. Jak wskazują Shiller (2012) oraz Akerlof i Shiller (2015), zmiany w zakresie rozwoju systemu jakości informacji powinny być kluczowym obszarem zmian instytucjonalnych po kryzysie finansowym z przełomu 2007 i 2008 roku. W jego opinii informacja finansowa ma taką samą istotność jak informacja medyczna, a wzmocnienie narodowej infrastruktury informacyjnej, tj. upublicznianie informacji finansowej nie tylko dla potrzeb instytucji finansowych oraz regulatorów, ale dla samego społeczeństwa, zminimalizuje efekt społecznego zarażania i kaskady informacyjnej, co jest głównym powodem kształtowania się baniek spekulacyjnych. Poza tym Shiller $(2005,2010,2012)$ wielokrotnie wskazywał na potrzebę tworzenia prostego i zrozumiałego dla społeczeństwa opisu produktów finansowych, m.in. wzorowanego na informacji o wartości odżywczej produktów spożywczych. W podobnym tonie wypowiadają się Grune-Yanoff i Hertwig (2015, s. 150), wskazując, że rozwój FL powinien następować poprzez dostarczanie informacji dopasowanej do uwarunkowań zewnętrznych (ang. boosts). W ramach koncepcji instytucjonalnych rozwój FL powinien zatem przebiegać nie w ramach tradycyjnej edukacji finansowej, ale na gruncie podejścia heurystycznego, łączącego właściwie przygotowaną informację i odpowiedni system zachęt. Przykładowo Willis (2011, s. 432), odnosząc się do komponentu 1 i 2 instytucjonalnego modelu oszczędzania, przedstawionego w tabeli 4, wskazuje: „edukacja finansowa, związana z planowaniem emerytury, okazała się kosztowniejsza i mniej efektywna, aniżeli narzędzia wyboru opcji domyślnej”. Skuteczność tych prostych mechanizmów potwierdziły badania prowadzone przez organizację Which?, opisane przez Halperna (2015, s. 177). Wykazały one, że mniej niż 50\% badanych była w stanie wybrać najtańszy kredyt hipoteczny spośród pięciu oferowanych kredytów i jedynie trzech kryteriów wyboru, a tylko 3\% była w stanie poprawnie nadać im rangi (od najtańszej do najdroższej opcji). Gdy natomiast dodano miernik - całkowity koszt posiadania kredytu hipotecznego (ang. the total cost of the mortgage) w okresie dwóch pierwszych

Halperna (2015, s.149) funkcjonującej pod akronimami EAST (ang. Easy - łatwy w odbiorze, ang. Attractive - atrakcyjna formuła przekazu, ang. Social - uwzględniający wpływ społeczny, ang. Timely - zrealizowany w odpowiednim czasie). 
lat, liczba poprawnych wskazań wzrosła do 70\%, tych zaś, którzy byli w stanie nadać im rangi wzrosła do 36\% (Halpern, 2015).

Problem nie tkwi zatem w braku świadomości potrzeby oszczędzania, ale w niewystarczającej motywacji do rozpoczęcia tego procesu (Thaler \& Benartzi, 2004). Nieefektywne okazują się również tradycyjne narzędzia polityki gospodarczej, które poprzez subwencje mają zachęcać jednostkę do oszczędzania emerytalnego. Przykładowo Chetty, Looney i Kroft (2009) wskazali, że taka forma "motywowania do oszczędzania” przekonuje jeszcze bardziej, ale tylko tych, którzy już oszczędzają na emeryturę znaczącą część swojej pensji, natomiast w przypadku osób, które tego nie robią, efekt jest praktycznie niezauważalny. W podobnym tonie wypowiadali się odnośnie do rynku amerykańskiego Choi, Laibson i Madrian (2011), podkreślając, że przed wprowadzeniem heurystyki opcji domyślnej, pomimo znaczących ulg podatkowych w przypadku oszczędzania na emeryturę, przeważająca liczba osób z nich nie korzystała. Dlatego też drugi z przypadków sugeruje, że jednym z najlepszych sposobów rozpoczęcia samego procesu oszczędzania jest brak aktywnej decyzji o samym akcie oszczędzania. Rozwiązaniem problemu motywacyjnego może być heurystyka opcji domyślnej (ang. default options), minimalizująca wysiłek poznawczy poprzez proponowanie wyborów automatycznych (bez konieczności podejmowania decyzji). Zamiast decyzji o rozpoczęciu oszczędzania decydent jest zobowiązany do dokonania wyboru o nierozpoczynaniu oszczędzania. Jak pokazują badania, zmiana wyboru z aktywnego na pasywny znacząco zwiększa liczbę osób przystępujących do dobrowolnych programów emerytalnych, jak również gromadzonych na nich kwot (Madrian \& Shea, 2001; Thaler \& Benartzi, 2004; Thaler, 2015). Jak wskazują Han i Sherraden (2009), szczególną efektywność tych narzędzi obserwuje się wśród osób o niskich dochodach. Ponadto zdaniem Willisa (2011, s. 432) „edukacja finansowa związana z planowaniem emerytury okazała się kosztowniejsza i mniej efektywna, aniżeli narzędzia wyboru opcji domyślnej”.

W trzecim przypadku, jak podkreślają Johnson i Sherraden (2007), wprowadzenie odpowiedniego systemu zachęt (premie za: dołączenie do projektu, uczestnictwo w modułach kursów z edukacji finansowej, systematyczne wpłaty, ukończenie projektu, kontynuację projektu na wyższych poziomach edukacji) powoduje, że szczególnie osoby z gospodarstw domowych o niskich dochodach mogą otrzymać w formie premii nawet dwu- lub trzykrotność zaoszczędzonych środków. Ci sami autorzy piszą, że dla niektórych rodzin oznacza to pokrycie kosztów dwóch lat edukacji wyższej. W Polsce zbliżonych do opisanego powyżej modelu brakuje. Efekt ten w opinii Beverly i Sherradena (1999) może być dodatkowo wzmocniony poprzez system zachęt finansowych promujących 
uczestników bonusami za zainicjowanie, kontynuację (im dłużej, tym więcej) i systematyczność wpłat na konto oszczędnościowe.

W czwartym przypadku, jak pokazuje przegląd dokonany przez Mullainathana (2006), wiele osób o niskich dochodach preferuje wręcz brak płynności przy tworzeniu oszczędności. Wybierają one narzędzia finansowe, które uniemożliwiają im dostęp do środków finansowych, dopóki cel finansowy, jaki został założony, nie zostanie zrealizowany. $\mathrm{W}$ ten sposób gospodarstwa domowe o niskich dochodach, rozumiejąc swoją sytuację finansową, poszukują narzędzi, które będą wspierać je $\mathrm{w}$ „walce $\mathrm{z}$ własnymi pokusami i samokontrolą”. Z powyższych rozważań wynika, że istnieje potrzeba przebudowy rozwiązań instytucjonalnych i narzędzi finansowych, które będą mieć znaczenie dla gospodarstw domowych o niskich dochodach. Ten sam autor proponuje nawet nowy rodzaj ekonomii instytucjonalnej, która nie tylko rozstrzyga problemy pomiędzy ludźmi (ang. between institutions), ale przede wszystkim rozwiązuje dylematy poznawcze samych ludzi (ang. within institutions) (Mullainathan, 2006, s. 380). W świetle tej koncepcji instytucje mogą pomóc osobom o niskich dochodach rozwiązać szereg trudności poznawczych, m.in. problem samokontroli, poprzez odpowiednią architekturę instytucji wspierających procesy oszczędzania (Mullainathan, 2007). Nie jest to podejście nowe. Pisał już o tym Shelling (1984, s. 70), wskazując, że „potrzebujemy systemowego podejścia do analizy ludzkich nawyków lub słabości w ważnych dla życia wymiarach: ich ułomności, uwarunkowań, w których te ułomności występują, oraz informacji, komunikacji, jak również instytucjonalnych narzędzi stworzonych w celu ich opanowania”.

\section{Wnioski}

Podsumowując, należy wskazać, że nie będzie możliwe zrozumienie ograniczonego oszczędzania w gospodarstwach domowych o niskich dochodach lub jego zaniechania bez analizy szerszego kontekstu instytucjonalnego. Gospodarstwa domowe o niskich dochodach nie mają zbyt wiele bodźców instytucjonalnych, aby oszczędzać. Jak słusznie pisał Elster (2000, s. 28): ,jeśli ludzie nie mają motywacji, to nie mogą być motywowani, aby ją zdobywać". Znakomitym przykładem jest tutaj edukacja dzieci, uznawana za jeden z najbardziej efektywnych sposobów walki z problemem ubóstwa na świecie. Jeśli nawet bowiem gospodarstwa domowe o niskich dochodach mają dostęp do powszechnej edukacji, to nie będą z niej korzystać, nie widząc szybkich efektów, jakie ona przyniesie ich członkom (Jarosz, 2008; Sen, 1999). Trudno zatem winić członków tych gospodarstw 
domowych za ten sposób myślenia. Analogicznie: wybory finansowe bardzo często podejmowane są na podstawie tego, co dla tych osób ma sens w danym momencie. W przypadku finansowania edukacji właściwym rozwiązaniem byłby kolejny członek w gospodarstwie domowym, który pracuje i otrzymuje stałe wynagrodzenie, zamiast przez kolejnych kilka lat być na utrzymaniu rodziny.

Pomimo istniejących ograniczeń indywidualnych i instytucjonalnych gospodarstwa domowe o niskich dochodach są w stanie radzić sobie z wieloma trudnościami finansowymi. Jak wskazuje Deaton (1991), wiele spośród gospodarstw domowych o niskich dochodach można zaliczyć do grupy tzw. „oszczędzających z wysoką częstotliwością" (ang. high frequency savers). Borykające się z problemami finansowymi gospodarstwa muszą oszczędzać niewielkie sumy praktycznie $\mathrm{w}$ nieskończoność, równoważąc tym samym konsumpcję w krótkim okresie. W gruncie rzeczy gospodarstwa te oszczędzają, ale poprzez wydawanie tych środków na liczne planowane i nieplanowane wydatki. Z kolei w opinii Banerjee i Duflo (2011) członkowie gospodarstwa domowego o niskich dochodach muszą być bardzo wprawnymi ekonomistami, aby przetrwać. Mullainathan i Shafir (2014) wskazują, że ze względu na fakt ciągłego zmagania się $\mathrm{z}$ „napiętym budżetem” gospodarstwa domowe o niskich dochodach muszą być bardzo elastyczne finansowo, ażeby efektywnie zarządzać środkami. Ta trudna sytuacja w pewien sposób „hartuje” osobowość członków gospodarstw domowych. Niestety poprzez rezygnację z wielu potrzeb podstawowych może także zagrażać integralności i dobrobytowi gospodarstwa domowego.

Wsparcie gospodarstw domowych o niskich dochodach w procesie oszczędzania nie będzie możliwe bez skutecznie funkcjonujących instytucji, zarówno tych formalnych, jak i nieformalnych. Wilkin (2016), który dokonuje przeglądu definicji instytucji, wyraźnie wskazuje, że współczesne definicje dodają do klasycznych pierwowzorów kontekst społeczny. Ten ostatni natomiast bardzo często decyduje o powodzeniu działania formalnych instytucji, szczególnie gdy tworzą one przepisy prawa zgodne z kulturowo ugruntowanymi sposobami myślenia i postępowania (Sen, 1987, 1999). Na podobnym stanowisku stoi Shiller (2012), wskazując, że innowacyjne narzędzia finansowe są bardzo często rezultatem obowiązujących w danym kraju tradycji i norm kulturowych.

Takim wsparciem dla gospodarstw domowych o niskich dochodach może i powinna - być tzw. heurystyczna edukacja finansowa (ang. heuristic driven education) (Altman, 2012; Drexler, Fischer \& Schoar, 2011; Gigerenzer, 2008, 2015). Heurystyczna edukacja finansowa to proces edukacyjny, która obniża nadmierny optymizm i likwiduje iluzję nierealistycznej kontroli nad własnymi finansami osobistymi. Według Gigerenzera (2015, s. 246) skuteczna edukacja 
heurystyczna to taka forma kształcenia, która łączy rozwój trzech głównych kompetencji: myślenia statystycznego, korzystania z heurystyk decyzyjnych oraz psychologii ryzyka. Pisząc o myśleniu statystycznym, należy mieć na uwadze rozwiązywanie problemów praktycznych, uwzględniających matematykę tzw. niepewności, a nie matematykę tzw. pewności, znaną z edukacji matematycznej na poziomie szkoły podstawowej i średniej. Heurystyczna edukacja finansowa może zatem realnie zmieniać postawy finansowe i z tego powodu powinna być w Polsce traktowana nie jako uzupełnienie kompetencji młodych ludzi, ale stanowić zagadnienie będące obowiązkową częścią kształcenia w szkołach podstawowych i średnich (jak dzieje się to w badaniach PISA realizowanych przez organizację $\mathrm{OECD})$.

Podsumowując, największy potencjał wsparcia tych, którzy go najbardziej potrzebują, może tkwić we właściwie funkcjonujących instytucjach. $Z$ tego powodu programy socjalizacji i edukacji finansowej bez właściwie zaprojektowanych narzędzi finansowych są dalece niewystarczające. To, czego potrzebujemy, aby uniknąć powtórki kryzysu finansowego z 2007/2008 roku, to w opinii Shillera (2012, s. XVII) „lepsze narzędzia finansowe, a nie mniejsza aktywność finansowa". Adekwatne instytucje powinny w opinii Atkinson i Messy (2012) pozwalać przezwyciężać ograniczenia psychologiczne i zmieniać postawy oszczędnościowe członków gospodarstw o niskich dochodach. Tworzenie tych mechanizmów nie jest propozycją teoretyczną, dopiero zyskującą uznanie wśród badaczy zajmujących się ekonomią instytucjonalną, ale kierunkiem badawczym, który odgrywa istotną rolę w praktyce życia społeczno-gospodarczego. Thaler (2015) wskazuje, że już 136 krajów stworzyło rozwiązania instytucjonalne opierające się na dorobku ekonomii behawioralnej i ewolucyjnej, a 51 z nich utworzyło specjalne organy państwowe zajmujące się tworzeniem tego typu rozwiązań dla praktyki gospodarczej.

\section{Bibliografia}

Ajzen, I., \& Fishbein, M. (1980). Understanding attitudes and predicting social behavior. Englewood Cliffs: Prentice-Hall.

Akerlof, G., \& Shiller, R. (2015). Phishing for Phools: The Economics of manipulation and Deception. New York: Princeton University Press.

Altman, M. (2012). Implications of Behavioral Economics for Financial Literacy and Public Policy. Journal of Socio-Economics, 41(5), 677-690. https://doi.org/10.1016/j. socec.2012.06.002

Antonides, G., \& van Raaij, W. F. (2003). Zachowanie konsumenta. Podręcznik akademicki. Warszawa: PWN. 
Atkinson, A., \& Messy, F. A. (2012). Assessing Financial Literacy in 12 Countries An OECD Pilot Exercise. Netspar Discussion Papers, 10, 657-665. https://doi. org/10.2139/ssrn.1809679

Banerjee, A. V., \& Duflo, E. (2011). Poor economics. London, GBR: Penguin Books.

Banerjee, A. V., \& Mullainathan, S. (2010). The Shape of Temptation: Implications for the Economic Lives of the Poor. NBER Working Paper, 15973. Pobrano z: http:// www.nber.org/papers/w15973 (20.02.2020). https://doi.org/10.3386/w15973

Bertrand, M., Mullainathan, S., \& Shafir, E. (2006). Behavioral economics and marketing in aid of decision making among the poor. Journal of Public Policy \& Marketing, 25(1), 8-25. https://doi.org/10.1509/jppm.25.1.8

Beverly, S. G., \& Sherraden, M. (1999). Institutional determinants of saving: implications for low-income households and public policy. Journal of Socio-Economics, 28(4), 457-473. https://doi.org/10.1016/S1053-5357(99)00046-3

Białowąs, S. (2013). Zachowania oszczędnościowe w polskich gospodarstwach domowych. Postawy, determinanty, model. Poznań: Wydawnictwo Uniwersytetu Ekonomicznego w Poznaniu.

Bucher\&Koenen, T., \& Lusardi, A. (2011). Financial literacy and retirement planning in Germany. Journal of Pension Economics and Finance, 10(4), 565-584. https://doi. org/10.1017/S1474747211000485

Chetty, R., Looney, A., \& Kroft, K. (2009). Salience and taxation: theory and evidence. American Economics Review, 99(4), 1145-1177. https://doi.org/10.1257/aer.99.4.1145

Choi, J. J., Laibson, D., \& Madrian, B. C. (2011). $\$ 100$ Bills on the Sidewalk: Suboptimal Investment in 401(k) Plans. The Review of Economics and Statistics, 93(3), 748-763. https://doi.org/10.1162/REST_a_00100

Collins, J. M. (2015). Paying for the Unexpected: Making the Case for a New Generation of Strategies to Boost Emergency Savings, Affording Contingencies, and Liquid Resources for Low-Income Families. W: J. M. Collins (Ed.), Fragile balance: emergency savings and liquid resources for low-income consumers (s. 1-16). New York: Palgrave MacMillan.

Cucinelli, D., Trivellato, P., \& Zenga, A. (2019). Financial Literacy: The Role of the Local Context. The Journal of Consumer Affairs, 53(4), 1874-1919. https://doi.org/10.1111/ joca. 12270

Deaton, A. (1991). Saving and Liquidity Constraints. Econometrica, 59(5), 1221-1248. https://doi.org/10.2307/2938366

Drexler, A., Fischer, G., \& Schoar, A. (2011). Keeping it Simple: Financial Literacy and Rules of Thumb. American Economic Journal: Applied Economics, 6(2), 1-31. https://doi.org/10.1257/app.6.2.1

Elster, J. (2000). Ulysses Unbound. Cambridge: Cambridge University Press. 
Gorbachev, O. (2011). Did Household Consumption Become More Volatile? The American Economic Review, 101(5), 2248-2270. https://doi.org/10.1257/aer.101.5.2248

Grune-Yanoff, T., \& Hertwig, R. (2015). Nudge Versus Boost: How Coherent Are Policy and Theory? Minds and Machines, 26(1-2), 169-183. https://doi.org/10.1007/ s11023-015-9367-9

Halpern, D. (2015). Inside the Nudge Unit. How small changes can make a big difference. London: WH Allen.

Han, C. K., \& Sherraden, M. (2009). Do institutions really matter for saving among low-income households? A comparative approach. Journal of Socio-Economics, 38(3), 475-483. https://doi.org/10.1016/j.socec.2008.07.002

Harasim, J. (red.). (2007). Oszczędzanie i inwestowanie indywidualne w Polsce. Katowice: PTE.

Harasim, J. (red.). (2010). Oszczędzanie i inwestowanie w teorii i praktyce. Katowice: PTE. Iwanek, M., \& Wilkin, J. (1997). Instytucje i instytucjonalizm w ekonomii. Warszawa: Wydawnictwo Uniwersytetu Warszawskiego.

Jarosz, M. (red.). (2008). Wykluczeni. Wymiar społeczny, materialny i etniczny. Warszawa: ISN PAN.

Johnson, E., \& Sherraden, M. S. (2007). From Financial Literacy to Financial Capability among Youth. Journal of Sociology \& Social Welfare, 34(3), 119-146.

Klapper, L., Lusardi, A., \& Panos, G. A. (2013). Financial literacy and its consequences: Evidence from Russia during the financial crisis. Journal of Banking \& Finance, 37, 3904-3923. https://doi.org/10.1016/j.jbankfin.2013.07.014

Kłopocka, A. (2018). Skłonność gospodarstw domowych do oszczędzania a wiedza finansowa. Bank i Kredyt, 49(5), 461-492.

Kochanowicz, J., Mandera, S., \& Marody, M. (2007). Kulturowe aspekty transformacji ekonomicznej. Warszawa: Instytut Spraw Publicznych.

Lusardi, A., Schneider, D. L., \& Tufano, P. (2011). Financially fragile households: evidence and implications. NBER Working Paper, 17072, 83-134. https://doi.org/10.3386/ w17072

Madrian, B., \& Shea, D. (2001). The Power of Suggestion: Inertia in 401(k) Participation and Savings Behavior. Quarterly Journal of Economics, 116(4), 1149-1187. https:// doi.org/10.1162/003355301753265543

Mullainathan, S. (2006). Better choices to reduce poverty. W: A. B. Banerjee, R. Benabou, \& D. Mookherjee (Eds.), Understanding poverty (s. 379-288). Oxford: Oxford University Press.

Mullainathan, S. (2007). Psychology and Development Economics. W: P. Diamond, \& H. Vartiainen (Eds.), Behavioral Economics and its Applications (s. 85-114). Princeton/Oxford: Princeton University Press. 
Mullainathan, S., \& Shafir, E. (2014). Scarcity. The true cost of not having enough. London: Penguin Books.

North, D. C. (1991). Institutions. The Journal of Economic Perspectives, 5(1), 97-112. https:// doi.org/10.1257/jep.5.1.97

Rószkiewicz, M. (2004). Skłonność Polaków do oszczędzania w świetle finansów behawioralnych. Ekonomista, 5, 675-695.

Rószkiewicz, M. (2006). Attitudes Towards Saving in Polish Society During Transformation. Social Indicators Research, 78, 429-452. https://doi.org/10.1007/s11205005-1605-8

Rószkiewicz, M. (2014). Objective and subjective factors shaping saving behaviours the case of Polish households. International Journal of Consumer Studies, 38(6), 602-611. https://doi.org/10.1111/ijcs.12129

Schreiner, M., \& Sherraden, M. (2007). Can the poor save? Savings and Asset Building in Individual Development Accounts. New York: Aldine de Gruyter.

Sen, A. (1987). On ethics and economics. Malden: Blackwell Publishing.

Sen, A. (1999). Development As Freedom. Oxford: Oxford University Press.

Shelling, T. (1984). Choice and consequences. Perspectives of an errant economist. Cambridge: Harvard University Press.

Sherraden, M. S. (2013). Building blocks of financial capability. W: J. M. Birkenmaier, M. S. Sherraden, \& J. C. Curley (Eds.), Financial Capability and Asset Building: Research, Education, Policy, and Practice (s. 1-43). Oxford: Oxford University Press.

Sherraden, M. (1991). Assets and the Poor: A New American Welfare Policy. New York: M. E. Sharpe.

Sherraden, M., Schreiner, M., \& Beverly, S. (2003). Income, institutions, and saving performance in individual development accounts. Economic Development Quarterly, 17(1), 95-112. https://doi.org/10.1177/0891242402239200

Shiller, R. J. (2005). Irrational Exuberance (second edition). New York, USA: Crown Business.

Shiller, R. J. (2010). How nutritious are your investments? Project Syndicate: A World of Ideas. Pobrane z: http://www.project-syndicate.org/commentary/shiller71/ English (20.02.2020).

Shiller, R. J. (2012). Finance and the Good Society. Princeton/Oxford: Princeton University Press.

Son, J., \& Park, J. (2017). Effects of financial education on sound personal finance in Korea: Conceptualization of mediation effects of financial literacy across income classes. International Journal of Consumer Studies, 43(1), 77-86. https://doi. org/10.1111/ijcs.12486

Thaler, R. H. (1990). Saving, fungibility, and mental accounts. Journal of Economic Perspectives, 4(1), 193-205. https://doi.org/10.1257/jep.4.1.193 
Thaler, R. H. (1994). Psychology and saving policies. American Economic Review, 84(2), 186-192.

Thaler, R. H. (2000). From homo economicus to homo sapiens. Journal of Economic Perspectives, 14(1), 133-141. https://doi.org/10.1257/jep.14.1.133

Thaler, R., \& Benartzi S. (2004). Save More Tomorrow: Using Behavioral Economics to Increase Employee Saving. Journal of Political Economy, 112(S1), 164-187. https:// doi.org/10.1086/380085

Thaler, R., \& Sunstein, C. (2003). Libertarian Paternalism. American Economic Review, 93(2), 175-179. https://doi.org/10.1257/00028280332194700

Thaler, R., \& Sunstein, C. (2008). Nudge. Improving Decisions About Health, Wealth, and Happieness. London: Penguin Books.

Thaler, R. (2015). Misbehaving. How Economics Become Behavioural. London: Penguin Books.

Wilkin, J. (2016). Instytucjonalne i kulturowe podstawy gospodarowania. Warszawa: Wydawnictwo Naukowe Scholar.

Willis, L. E. (2011). Financial Education Fallacy. American Economics Review, 101(3), 429-434. https://doi.org/10.1257/aer.101.3.429

Xiao, J. J. (2008). Applying behavior theories to financial behavior. W: J. J. Xiao (Ed.), Handbook of consumer finance research (s. 69-81). New York: Springer.

\section{Streszczenie}

Celem artykułu jest przedstawienie argumentów teoretycznych wspierających następującą tezę badawczą: „Brak oszczędzania w gospodarstwach domowych o niskich dochodach wynika m.in. $\mathrm{z}$ braku instytucjonalnego wsparcia tych gospodarstw $\mathrm{w}$ realizowaniu zarówno krótko-, jak i długoterminowych planów oszczędnościowych”. Artykuł ma charakter metodyczny i przeglądowy. Zastosowano w nim metodę analizy krytycznej źródeł literaturowych. Wnioski formułują kryteria, jakie muszą spełniać rozwiązania instytucjonalne, aby skutecznie wspierały gospodarstwa domowe o niskich dochodach w realizacji ich celów oszczędnościowych.

SŁOWA KLUCzOWE: finanse gospodarstw domowych, wybory finansowe, instytucjonalne modele oszczędzania, narzędzia finansowe, behawioralna polityka gospodarcza

\section{Summary}

The main objective of the present article is to present theoretical arguments supporting the following research thesis: "Without institutional support low-income households will not be able to accomplish their short and long-term saving goals due to the specific financial situation". The article is of both methodical and review character. The critical review of international and domestic sources was applied to answer the research ques- 
tion. Conclusions indicate key institutional criteria which need to be met to support low-income households in their saving objectives.

KEYWORDs: Households finance, financial choices, institutional saving models, financial tools, behavioural public policy

Kody JEL: R20, D12, D14, I25, I32

\section{Nota o autorze}

Tomasz Potocki - dr hab. nauk ekonomicznych, profesor UR; Katedra Rynków, Finansowych i Finansów Publicznych, Instytut Ekonomii i Finansów, Uniwersytet Rzeszowski; główne obszary działalności naukowej: finanse gospodarstw domowych, finanse behawioralne, teoria wyborów, e-mail: tpotocki@ur.edu.pl; ORCID: 0000-0001-7309-7892. 